\title{
Problem-based psychiatry in a new undergraduate medical curriculum
}

\author{
Rajan Nathan, Trevor J. Gibbs and Kenneth C. M. Wilson
}

Traditional British undergraduate medical education has evolved with the development of medicine as a profession. However, despite dramatic progress in the provision of healthcare, the medical curriculum has remained mostly unchanged until recently. Conventional medical courses rely on the teacher-centred didactic setting of a lecture theatre to transmit vast quantities of information. This one-way traffic of facts is divided initially into the preclinical basic sciences and later into the medical specialties, with relatively little horizontal or vertical integration. Much of the assessment of students relies on their reproducing information as accurately as possible. This traditional format has been widely criticised (Lowry, 1992).

The information that a student is required to retain is excessive, of questionable relevance and soon becomes out of date. The assessment procedure involves regurgitation of information in an anxiety-provoking setting that does not encourage more than a superficial understanding. This form of assessment has become an end rather than a means to it. Thus, sight of the real purpose of medical education, that is, to enable the student to become a competent clinical practitioner and a lifelong learner, has been lost.

\section{Background to change}

In response to these criticisms, new and innovative curricula have been designed, which rely on student-centred courses where subject matter is integrated and learning is problem based. Such curricula have been introduced in medical schools across the globe. McMaster University in particular has been a pioneer in this respect (Neufeld \& Barrows, 1974). British medical schools have been less enthusiastic until recently. However, in 1991 the General Medical Council (GMC) strongly encouraged reform (General Medical Council, 1991). Subsequently many medical schools adopted piecemeal GMC recommendations. In October 1996, the Faculty of Medicine within the University of Liverpool took the bold step of introducing a completely new medical curriculum.

\section{New medical curriculum at Liverpool}

The course structure is based on a core curriculum plus options model with comprehensive integration of subject matter. The options are in the form of a series of special study modules. Objectives are defined in terms of skills and attitudes, as well as knowledge and understanding. Self-directed learning is emphasised in achieving these objectives through a problembased learning approach (Barrows \& Tambly. 1980). The curriculum is divided into three phases. Phase 1 in the first year introduces students to the science and practice of medicine. Although medical (clinical and communication) skills are introduced in the first year, actual clinical experience begins in Phase 2 (years 2-4). Students progress from understanding normality (year 2), through recognition of abnormality (year $3)$, to diagnosing disease and planning patient management (year 4). Phase 3 in the final year involves apprentice-based clinical experience. Problem-based learning modules, each lasting one or two weeks, run throughout the first four years.

\section{Problem-based learning}

This review focuses on problem-based learning. which forms a major part of the curriculum reform at the Faculty of Medicine in the University of Liverpool. Problem-based learning is an educational approach, at the core of which is the presentation of a real clinical situation (Bligh, 1995). Typically, about five students and a facilitator meet regularly. Schmidt (1983) describes the steps involved. His description is of limited value in that it implies a rigid format that is not in keeping with the general philosophy of this approach. However his account illustrates the processes involved. The first step, which 
involves activation of prior knowledge, is clarification of the terms used in the presentation. The problem then should be defined precisely. This allows analysis of the problem in terms of the underlying phenomena. By considering the questions raised, the group formulates learning objectives that are achieved through individual study using a variety of resources. When the group reconvenes, the new information is shared and applied to the original problem. This approach addresses many of the criticisms outlined above. Problem-based learning dispenses with the need for departmental segregation. By learning in the context of considering an actual clinical problem, the knowledge acquired is relevant to clinical practice. Problem-based learning produces conditions that have been shown by educational psychologists to facilitate learning (Engel, 1992). Such conditions include contextual learning, encoding specificity and the use of prior knowledge to organise and elaborate new information. In addition to these educational goals, problem-based learning encourages the development of further skills such as listening, summarising, collaborating, peer teaching and assessing.

\section{Problem-based peychiatry}

As mentioned, one of the main learning environments in the new course at Liverpool is the problem-based learning group. The psychiatry module, which lasts four weeks, is in the second half of Phase 2. The module is based on the core curriculum for psychiatry, which follows GMC recommendations (General Medical Council, 1993). The development and design of such a core curriculum has been described elsewhere (e.g. Nasser, 1996; Working Party of the Education Committee of the Royal College of Psychiatrists, 1997). Although there is variation, the same principles apply to the core curriculum for psychiatry at Liverpool. An overview of psychiatry in the rest of the problem-based curriculum will be presented here.

Within the problem-based learning setting, the groups are encouraged to refer to the four curriculum themes (Table 1). Thus psychosocial factors are seen as central. For each module, a convenor identifies the learning objectives. Table 2 lists the topics related to psychiatry that have

Table 1. Curriculum themes

1. Structure and Function in Health and Disease (biology and pathology)

2. Indlviduals, Groups and Society (the psychosocial dimensions of behaviour)

3. Population Perspective (epidemiology and public health)

4. Professional Values and Personal Growth been extracted from the module learning objectives document. Psychiatric issues are introduced at the earliest stage. In the first year "basic psychiatric assessment' is a learning objective of the 'stroke' module. The 'psychological dimensions of physical symptoms and illness behaviour' forms part of the 'indigestion module', which is the second module in the first year. Such liaison psychiatry themes recur throughout the modules. However, liaison psychiatry is not, as may have been anticipated with such an integrative approach, included at the expense of other areas of psychiatry. Substance misuse features heavily in the first year and a module in the second year is devoted to this topic. Furthermore, aspects of psychogeriatrics, child psychiatry, psychosexual medicine, learning disability, eating disorders and psychosis appear in the modules.

Table 2 does not include topics that, although important in psychiatry, are of equal importance in other specialties. Such topics, which include, for example, twin studies, neuro-anatomy, team work and compliance, are too numerous to list.

This review is based on the objectives defined by the module convenor. It should be remembered that the course in Liverpool is studentcentred. In practice, the degree to which facilitators of problem-based groups encourage adherence to the convenors' recommendations varies. The relationship between the convenors' objectives and those of the students remains to be determined.

\section{Comment}

Notwithstanding the methodological difficulties in examining problem-based learning, there is evidence of improved clinical performance. enhanced academic process and greater student and faculty satisfaction in comparison with traditional courses (Vernon \& Blake, 1993). However, the value of problem-based learning in relation to undergraduate psychiatry has not been examined specifically.

Although the topics listed in Table 1 are labelled 'psychiatry-related', an in-depth knowledge of these areas is not exclusive to psychiatrists. In fact, some other medical specialists or other professionals, such as psychologists, may be more familiar with certain areas. Such an overlap of educational responsibility is inevitable when analysing an integrated curriculum from the point of view of a specialist. The particular topics have been chosen as those that are of direct relevance to clinical practice in psychiatry. Although there has been a reduction in time specifically devoted to psychiatry (from eight weeks in the old curriculum to four in the new). this does not necessarily imply that undergraduate psychiatry 
EDUCATION AND TRAINING

Table 2. Psychiatry in problem-based learning modules

\begin{tabular}{|c|c|}
\hline Model (number) & Psychiatry-related toplcs \\
\hline $\begin{array}{l}\text { Year I } \\
\text { Indigestion (2) }\end{array}$ & $\begin{array}{l}\text { Psychological dimensions of physical symptoms and Iliness behaviour' } \\
\text { Tensions between scientific diagnosis and the caring treatment of the } \\
\text { patient }\end{array}$ \\
\hline Asthma (4) & Stigma' \\
\hline Diabetes (5) & Psychology of emotion \\
\hline Alcohol (6) & $\begin{array}{l}\text { Sociological concepts of behaviour and culture } \\
\text { Forensic aspects } \\
\text { Spectrum of problem-drinking, alcohol dependence, } \\
\text { alcohol-related problems } \\
\text { Identifying and assessing alcohol-related problems } \\
\text { Psychological principles of behaviour modification }\end{array}$ \\
\hline Anaesthesia (8) & Informed consent' \\
\hline Stroke (10) & $\begin{array}{l}\text { Psychological rehabilitation } \\
\text { Psychological impairment } \\
\text { Effects from individual and family viewpoints } \\
\text { Basic psychiatric assessment }\end{array}$ \\
\hline Wound healing (11) & Body image \\
\hline Smoking (13) & $\begin{array}{l}\text { Addictive behaviour } \\
\text { Personality and environment in addictive behaviour }\end{array}$ \\
\hline 'Cromwell Street Murders' (14) & $\begin{array}{l}\text { Forensic psychology } \\
\text { Bereavement and mourning } \\
\text { Psychological reactions }\end{array}$ \\
\hline Year 2 & \\
\hline Pregnancy (2) & $\begin{array}{l}\text { Drugs and alcohol } \\
\text { Psychological adjustment } \\
\text { Impact on the family unit } \\
\text { Demedicalisation of medical care }\end{array}$ \\
\hline Birth/lactation (3) & Attitudes to birth and parenthood \\
\hline The neonate (4) & $\begin{array}{l}\text { Interactional relationships } \\
\text { Effects of postnatal depression on baby development } \\
\text { Attachment formation }\end{array}$ \\
\hline Child development (6.7) & $\begin{array}{l}\text { Developmental milestones: cognitive, social, emotional } \\
\text { Family: life-cycle, parenting styles } \\
\text { Attention-deficit disorder } \\
\text { Impairment, disability and handicap' } \\
\text { Labelling } \\
\text { Learning disability }\end{array}$ \\
\hline $\begin{array}{l}\text { Puberty }(9)^{2} \\
\text { Drug misuse }(10)^{2} \\
\text { Sexual health and behaviour }(11)^{2}\end{array}$ & \\
\hline Nutrition, exercise and fitness (12) & $\begin{array}{l}\text { Public attitudes towards diet } \\
\text { Psychology of eating }\end{array}$ \\
\hline Acute abdominal pain (19) & $\begin{array}{l}\text { Non-organic causes } \\
\text { Munchausen's syndrome }\end{array}$ \\
\hline $\begin{array}{l}\text { Renal failure (20) } \\
\text { Joints and muscles (22) }\end{array}$ & $\begin{array}{l}\text { Psychosocial adaptation to chronic disease' } \\
\text { Medical and social models of dlsability } \\
\text { Managing patients who are suffering but are not diagnosed as ill }\end{array}$ \\
\hline $\begin{array}{l}\text { Old Age }(23)^{2} \\
\text { Years } 3 \text { and } 4 \\
\text { Paediatric surgery (28) } \\
\text { Road traffic accident (30) }\end{array}$ & $\begin{array}{l}\text { Down's syndrome } \\
\text { Psychological reactions to major trauma } \\
\text { Post-traumatic stress disorder } \\
\text { Bereavement }\end{array}$ \\
\hline $\begin{array}{l}\text { Accident in the home (31) } \\
\text { Psychiatry }(36,37)^{2} \\
\text { Palliative care (44) }\end{array}$ & $\begin{array}{l}\text { Non-accidental injury, self-inflicted injury } \\
\text { Attitudes towards death and dying } \\
\text { Psychological consequences of terminal illness } \\
\text { Normal and abnormal grief reactions and their management }\end{array}$ \\
\hline
\end{tabular}

1. Topics that appear in several modules. Only the first appearance is recorded.

2. Modules that are wholly or predominantly related directly to psychiatry. 
as a whole has been compromised; this can be determined only by formal evaluation. Some may see such changes as a threat to the integrity of psychiatry. Given the explicit aim of the course to meet the needs of future generalists - there is no attempt to maintain such integrity. Such wholesale revision of a medical curriculum produces anxieties for students and the faculty. Of particular concern is the desire for learning and assessment to be standardised.

Where does such widespread undergraduate medical curriculum revision leave psychiatrists? By the nature of their training (experiential and examination-orientated), psychiatrists should already be familiar with the philosophy underlying such a curriculum. Thus, psychiatrists can continue to play a major role in medical education by using their dual grounding in neuroscience and in the human aspects of medicine (Andreasen, 1996). To do so, psychiatrists need to be actively involved in the development and implementation of such educational innovations.

\section{References}

ANDREASEN, N. C. (1996) Body and soul (editorial). American Journal of Psychiatry, 163, 589-590.

BarRowS, H. S. \& TAMBLYN, R. M. (1980) Problem-Based Learning. New York: Springer.

Bugh, J. (1995) Problem based, small group learning. British Medical Journal, 311, 342-343.
ENGEL, C. R. (1992) Problem-based learning. British Journal of Hospital Medicine, 48. 325-329.

GenERAL MEDICAL CoUnCIL (1991) Undergraduate Medical Education. The Need for Change. London: General Medical Council.

- (1993) Tomorrow's Doctors: Recommendations on Undergraduate Medical Education. London: General Medical Council.

LOWRY, S. (1992) What's wrong with medical education in Britain? British Medical Journal, 308, 1277-1280.

NASSER, M. (1996) Psychiatry: a core curriculum for undergraduate medical students. Psychiatric Bulletin. 20. 230-233.

Neufeld, V. R. \& BARRows, H. S. (1974) The McMaster Philosophy': an approach to medical education. Journal of Medical Education, 49, 1040-1050.

SCHMIDT, H. G. (1983) Problem-based learning: rationale and description. Medical Education, 17, 11-16.

VERNON, D. T. A. \& BLAKE, R. L. (1993) Does problem-based learning work? A meta-analysis of evaluative research. Academic Medicine, 68, 550-563.

WORKING PARTY OF THE EDUCATION COMMTTEE OF THE ROYAL College of PSYCHIATRISTS (1997) Core psychiatry for tomorrow's doctors. Psychiatric Bulletin, 21, 522-524.

* Rajan Nathan, Specialist Registrar in Forensic Psychiatry, Scott Clinic, Rainhill Road, St Helens, Merseyside WZ9 5DR; Trevor J. Gibbs, Director of Community Studies, Department of Health Care Education, University of Liverpool L69 3GA; and Kenneth C. M. Wilson, Professor of Psychiatry of Old Age, EMI Academic Unit, St Catherine's Hospital, Church Road, Birkenhead LA2 OLQ

*Correspondence

\section{CAN: Camberwell Assessment of Need}

Mike Slade, Graham Thornicroft, Linda Loftus, Michael Phelan

\& Til Wykes

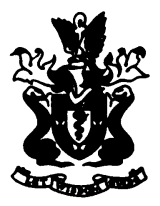

The Camberwell Assessment of Need (CAN) is a tried and tested approach to assessing the needs of the severely mentally ill which is suitable both for research studies and routine clinical use. Rigorously developed by staff at the Section of Community Psychiatry (PRiSM), Institute of Psychiatry, the CAN is suitable for use in primary care settings, specialist mental health teams, and social services. It will be of particular interest to care managers and mental health staff who wish to meet the legal requirement that the severely mentally ill receive a comprehensive needs assessment.

July 1999, £45.00, 144pp, Ringbound pack incl. photocopiable material, ISBN 1901242250

Available from Book Sales, Royal College of Psychiatrists, 17 Belgrave Square, London SW1X 8PG Tel +44 (0) 1712352351 (extension 146), Fax +44 (0) 1712451231 http://www.rcpsych.ac.uk 